\title{
A JUSTIÇA ESTÁ EM GREVE! (Farsa-balé)
}

\author{
SIMONE ZIED PINHEIRO'
}

1 Doutora em Estudos Literários (área de concentração: Teoria do Drama) pelo Programa de Pós-Graduação em Letras da UNESP/ Araraquara-SP.; Mestre em Fundamentos da Educação (área de concentração: Filosofia da Educação) pelo Programa de Pós-Graduação em Educação da UFSCar/SP.; Graduada em Pedagogia pela UFF/RJ; Pedagoga do ensino público municipal de Niterói/RJ. 


\section{Prefácio ou posfácio, a escolha é sua!}

Quando escrevi esta peça em 2008, inspirei-me na greve do setor judiciário carioca. Pensei na ironia da frase "a justiça está em greve" e o quanto seu significado é abrangente. Comecei a imaginar como seria o mundo se não houvesse mais justiça no planeta e, acabei me remetendo ao mito grego de Têmis e Diké: a primeira, uma titânide filha de Urano e Gaia, representa a justiça, a ordem, as leis e os costumes estabelecidos entre as divindades; a segunda, uma das Horas, fruto da relação entre Têmis e Zeus, encarna a justiça humana. Em uma das correntes jusfilósofas brasileiras essas duas entidades expressam respectivamente o Direito Natural e o Direito Positivo.

Comecei a fantasiar Têmis que, após gerar as outras duas Horas - Irene, a paz, e Eunômia, a disciplina -, se encontra insatisfeita com a humanidade e, por isso, nega-se a ter relações sexuais com Zeus a fim de evitar o nascimento de Diké, pois, de acordo com a personagem, pouco proveito se fez em relação às presenças da Paz e da Disciplina no mundo, assim, de nada vale todo o trabalho para gerar a Justiça Humana.

$\mathrm{Na}$ minha forma de pensar, tudo isso me soou tão cheio de ironia, desorganização cósmica e falta de responsabilidade humana frente a valores imprescindíveis como paz, justiça e disciplina, que, em termos morfológicos, imediatamente surgiu-me uma ideia burlesca: esta peça tinha de ser uma farsa!

E por que farsa-balé? Porque sou brasileira e estou acostumada às coisas terminarem em samba. Essa pode ser uma das respostas. Outra se relaciona com minha formação molieresca, o que aliás se evidencia de várias maneiras no texto dramatúrgico, seja por ser farsa, ou por ser farsa-balé (imaginem se a música fosse composta por Lully..)., seja por recorrer à mitologia grega, ou mesmo pelo modo como Zeus, Têmis e Hermes se entrelaçam na peça.

Questões, a meu ver, importantes como relacionamento entre pais e filhos, madrasta (ou padrasto) e enteados, deuses e seres humanos são aqui tratadas; assim como a denúncia da necessidade urgente de uma vida pautada em paz, justiça, harmonia, disciplina, amor, igualdade, etc. Algumas pessoas poderiam ver nisso uma diminuição da estética textual, já que a arte deve existir por si só, sem se preocupar com um aspecto educacional. Brecht, Boal e vários outros discordariam dessa proposição e falariam em arte engajada. Até mesmo os classicistas franceses alegariam a importância e a veracidade do provérbio "castigat ridendo morus"2, o qual, assevera René Bray, estampava uma das paredes do Petit Bourbon, onde Molière e sua trupe encenaram várias de suas peças. Honestamente, não sei como me posicionar teoricamente no que diz respeito a esse assunto, tanto não sei que após um ano não consigo finalizar outra peça que, ainda, escrevo, porque fico em dúvida se devo optar por um final prioritariamente estético ou que preze mais a ética, mas isso é um outro assunto. De qualquer maneira, entendi como importante refletir sobre a justiça e outros valores sociais que considero fundamentais à existência humana de qualidade - afinal esse foi o mote da peça - e a forma pela qual escolhi me expressar foi por meios dramatúrgicos.

Por fim, apenas mais um ponto desejo ressaltar. Ele diz respeito ao coro e ao corifeu: é necessária sua presença para alicerçar a farsa. De início, essa participação pode, traiçoeiramente, conferir à peça um ar mais sério, quase rompendo com a ideia inicial da farsa. Mas isso é uma percepção primeira, superficial; pois, ao lon-

\footnotetext{
2 Uma tradução livre do latim pode ser: rindo se castiga os costumes da sociedade.
} 
go da peça, percebe-se que são os mortais representados pelo coro e corifeu que mostram, por intermédio de seus raciocínios, dúvidas, solicitações e exigências, que se trata realmente de uma farsa, haja vista a maneira burlesca como os poderosos lidam com os mortais. Alguma alusão aos nossos governantes? Ou à religião? Isso depende da recepção de cada leitor/espectador.

\section{Personagens}

Têmis, a Justiça Natural

Zeus

Hermes

As Horas (possuem ar doce).

- Eunômia, a Disciplina

- Irene, a Paz

- Diké, a Justiça Terrena

As Moiras (possuem ar travesso, mas gracioso).

- Cloto, a fiandeira

- Láquesis, a sorteadora

- Átropos, a inflexível

Corifeu

Coro (formado por no mínimo três atores e/ou atrizes e no máximo por dez).

\section{Trajes dos personagens:}

Têmis: tem cabelos compridos e adornados com uma tiara dourada, veste uma bata branca com faixa amarrada três vezes na cintura e uma longa saia, também branca, até os pés, que estão descalços. A bata deve ter suas mangas curtas presas por uma fivela dourada.

Zeus possui barba e cabelos curtos. Físico atlético. Usa apenas um sarongue cor de linho cru, que, continuado pelas costas, faz a vez de um xale.

Hermes possui sandália de couro com pequenas asas, veste uma capa e túnica, ambas cinzas. Cabelos enrolados, não tão curtos, mas sem serem longos e cavanhaque em formato triangular.

As Horas e as Moiras: vestem-se com túnicas brancas, sem faixa ou cinto, e cabelos adornados com pequenas margaridas brancas. Possuem ar juvenil e são graciosas, apesar de serem quem são, as Horas e as temíveis Moiras. As mangas estão afiveladas por pequenas margaridas.

O Coro e o Corifeu: vestem túnicas pretas, amarradas na cintura por faixas igualmente pretas e usam adorno escuro nos cabelos. Estão descalços. O Corifeu se distingue do coro pelo cinto dourado na cintura. As mangas de todas as túnicas devem estar presas por fivelas douradas.

\section{A Justica está em Greve!}

\section{(Farsa-balé)}

Cenário: O monte Olimpo, morada dos deuses. O cenário é dividido em três cenas que ocorrem simultaneamente: do lado esquerdo do palco, encontra-se Hermes, o deus mensageiro, e, ali, deve haver um pedaço de ruína de uma pilastra branca 
para que ele se sente quando for necessário; no centro, há pilastras gregas brancas, representando a morada dos deuses, onde os personagens agem durante a farsa; do lado direito, o coro com seu chefe, o Corifeu. Há uma pequena arquibancada para que o coro e o Corifeu possam se sentar quando não estão atuando diretamente. A iluminação deve seguir prioritariamente quem está em evidência na cena; todavia, não deve haver um foco de luz único nem efeito de escuridão nos demais personagens em pausa. É importante que o público veja as reações dos demais personagens, supostamente "fora de cena"; por exemplo, é fundamental que a audiência acompanhe a postura desleixada de Hermes, mesmo quando ele não está atuando em primeiro plano. Após o prólogo, Hermes deve sentar-se e, vez ou outra, bocejar, mostrando tédio e total desinteresse pelas questões postas durante a farsa, salvo quando as indicações são contrárias.

\section{Prólogo}

(Do lado esquerdo do palco).

\section{Hermes:}

(Limpa a voz solenemente).

Como mensageiro dos céus

Não posso me negar

A romper todos os véus

E a história anunciar.

Zeus, pai e dirigente,

Do Olimpo a chacoalhar

Envia-me a toda gente

Para o caso divulgar.

Têmis achou por bem

Cobrir-se com pijama grosso

E no lugar de dizer amém

Ela deixou Zeus sem osso.

(Faz um gesto chulo).

Foi uma situação tamanha

Condição assim nunca se ouviu

Mais complexa do que estranha

Pois Urânio a Gaia impediu.

E Cronos a Rea negou

A maternidade dos seus

Comendo filhos atrasou

A suplantação do herdeiro Zeus.

Esse, porém, foi mais esperto

Em vez de fundar uma patriarcal dinastia

Colocou irmãos e filhos por perto

E no Olimpo, com os outros, se fazia.

O diferente não é o que aconteceu,

Pois outros deuses já negaram.

Ou porque gerar filhos não Ihes ocorreu

Ou porque simplesmente não os apreciaram. 
Mas o fato da ser uma deusa a recusar

Criou furor no Monte Olimpo

Têmis teimando em pausar

O nascimento limpo

De Diké, levando Zeus a se indignar

E gritar "eu quero, eu quero!"

"Se a mulher me faz resignar

Acabo que me desespero!"

Ah, Têmis malvada,

Acabe com esse louco jejum

Libere logo a bacalhoada

E não dispense mais nenhum!

Engendre Diké, sua filha,

Não lute contra o destino

Pois o humano no fundo dedilha

Gosto e interesse pelo tino.

E algum dia, quem sabe?

De tanto se falar em Justiça

A Humanidade logo acabe

A tornar sua vida castiça,

Agora, chega de enrolar

A platéia que já se cansa

Porque não é normal falar

Com tanto verso e com pouca dança.

(Hermes percebe que não estava dançando e faz uns passos desajeitados de dança.

Olha para o público e se desculpa com gestos).

À farsa...

(Faz um convide com as mãos, que a iluminação deve seguir, para o centro do palco).

\section{A Farsa}

(Do lado direito do palco).

Corifeu: Têmis, a Justiça Divina está em Greve!

Coro: Em greve? (Os participantes do coro se olham entre si procurando entender a frase. Fazem gestos de que não a compreendem, mas asseguram). Em greve!

(No centro do palco).

Têmis: (Batendo com a mão cerrada na outra palma da mão, com expressão de inflexibilidade). Não transo, não transo, não transo!

Zeus: Não fale assim, meu amor!

Têmis: Nem vem com essa "de meu amor"... Olhe que Hera ouve e depois o põe para correr!

Zeus: Esqueça-se dela, é só em você que eu penso!

Têmis: Ih, essa fala está mais para pagodeiro fajuto do que para verdade... Você fala isso para todas...

Zeus: Ah, Tetê... 
Têmis: Tetê não! Têmis! Não estou podendo ver a sua cara, Zeus!

Zeus: Ah, não faça assim... Me chame de Zezinho, vai?

Têmis: (Resmunga). Hunf! (De rabo de olho, começa devagar a ceder).

Zeus: (Percebe que a zanga de Têmis está aos poucos desaparecendo). Vai, me chame de Zezinho. No Olimpo inteiro só você me chama assim. Gosto tanto! Sinto uma vontade... (Agarra Têmis por trás).

Têmis: (Ri e finge não querer). Pare, Zezinho! Não adianta que eu não quero!

(Hermes, do lado esquerdo do palco, mostra-se entediado com essa conversa boba do casal).

Zeus: Quer sim, quer sim que eu conheço você!

Têmis: (Risos. Até agora ela estava de costas para Zeus, vira-se de frente e o beija. Zeus a corresponde e a agarra mais. Ela se desprende dele). Não, Zezinho. É sério! Eu não quero!

Zeus: (Sem entender). Mas por quê?

Têmis: Porque não.

Zeus: Tô com bafo de cebola? Ainda agora eu estava em uma festança de Apolo que tinha umas carnes aceboladas maravilhosas. Será que é isso? (Dá uma baforada na mão). Parece que não...

Têmis: Não...

Zeus: É o meu desodorante que já expirou a validade? (Cheira suas próprias axilas). Não, parece que não...

Têmis: Não...

Zeus: Tô com chulé? (Cheira seu próprio pé, que está descalço). Ué, parece que não...

Têmis: Não...

(Antes que Zeus cheire mais alguma parte de seu corpo, Têmis segura suas mãos para lhe prender a atenção).

Têmis: Não é nada disso, Zezinho! (Tom de apaixonada). Você é perfeito!

Zeus: (Sorri, mas está um pouco confuso). Então qual é o problema?

Têmis: Eu não quero parir Diké!

Zeus: Como assim?

Têmis: Simples, Zezinho, eu não quero gerar Diké!

Zeus: Por que não?

Têmis: Porque não vale a pena!

Zeus: As meninas andam fazendo muita traquinagem? Ah, que eu as chamo agora aqui e as ponho de castigo já-já. Espere só um pouco...

Têmis: Não, Zeus! Irene e Eunômia são uns doces, não dão trabalho nenhum!

Zeus: Então são as Moiras?

Têmis: Que nada, elas passam o dia a fiar, sortear e fazer cumprir o destino dos mortais. Não tenho do que me queixar!

Zeus: Ué, se elas não a aborrecem, nem dão trabalho, por que não vale a pena? (Com chamego). Ah, Tetê, vamos fazer Diké, vamos?

Têmis: (Um pouco chateada). Você não entende mesmo, né, Zeus?! Já falei, não quero! Não transo, não transo, não transo!

(Do lado esquerdo do palco).

Hermes: 
Ai, voltar ao início da farsa não!

Embrulha meu estômago só de pensar

Que as baboseiras do fanfarrão

terei de tudo ouvir e me calar!

(Do centro do palco).

Têmis: (Defendendo Zeus). Fanfarrão, não! Respeito com seu pai! Zezinho é tudo de bom! (Acaricia os cabelos de Zeus. Para Hermes, com certa dose de raiva). E você aí, chato que dói, que fala só rimando, escolhe um termo melhor, porque bacalhoada têm aí as suas negas! É, está achando que não prestei a atenção no seu discurso inicial? Prestei sim e tá me faltando isso aqui ó (Mostra com os dedos uma porção bem pequena). para eu atravessar o palco e lhe dar um boa porrada que é o que você merece, seu canastrão.

(Do lado esquerdo do palco).

Hermes:

(Desculpa-se sincero).

É a inexperiência da poeta

Em rimas criar com destreza

E acaba por se tornar abjeta

$\mathrm{Na}$ arte sem demonstrar clareza.

(Do centro do palco).

Têmis: Ah, tá bom! Escondendo a sua incompetência debaixo das asas da criadora... se você pensa que eu caio nessa...

Zeus: (Intervém na discussão, porque ele quer transar com Têmis). Meu amor, deixe esse Hermes paspalhão de lado. Gastar seu tempo com ele para quê? (Beija-a. Têmis ainda está nervosa, ameaça dizer mais um desaforo para Hermes agora que se sente respaldada, mas cede aos beijos de Zeus).

(Hermes faz um gesto entediado e uma expressão facial, que evidenciam que não vale a pena discutir com Têmis. Senta-se com ar de enfado).

Têmis: Zezinho, falei que não vou transar...

Zeus: Ah, transa, transa sim... vamos fazer uma Diké bem lindinha!

Têmis: Para quê? Para quê? Fizemos Eunômia, a Disciplina, com tanto carinho para os humanos aprenderem a organizar a vida e assegurar o equilíbrio da sociedade. Mas você viu o que eles fizeram?

Zeus: (Beijando o pescoço de Têmis, não presta muito a atenção no que ela diz). Não, o que eles fizeram?

Têmis: Ofenderam a Mimia de modo intolerável?

Zeus: (Presta a atenção repentinamente). Ofenderam a minha filha?

(Hermes passa a se interessar aos poucos pelo diálogo do casal).

Têmis: Ofenderam sim!

Zeus: Aqueles mortais?

Têmis: Eles mesmos!

Zeus: Aquelezinhos que Prometeu se ferrou porque quis ajudá-los dando o fogo sagrado?

Têmis: Exatamente! Mas não vamos entrar muito no mérito de Prometeu, porque 
teve um poeta cismando em querer me fazer a mãe dele. Tô fora! Vamos falar dos mortais que insultaram sua filhinha! Esses mortais que não valem nada...

Zeus: E agora eles ofenderam a minha Eunômia? Minha Mimia?

Têmis: Não só a ela, mas a Irene também!

Zeus: (Furioso). Ireninha também?

Têmis: (Gostando porque finalmente prendeu a atenção de Zeus). Principalmente ela!

Zeus: Ireninha, meu xodó?

Têmis: Ireninha sim, que guarda com tanta tranquilidade as suas portas celestes e que não arruma confusão com ninguém!

Zeus: (Com ódio que só os deuses possuem). Ah, vou acabar com a linhagem dos mortais! (Troveja). Quem eles pensam que são para ofender as filhas do próprio Zeus? (Troveja novamente).

Têmis: (Concordando). Isso mesmo! Que absurdo! Uma ofensa a suas filhas é praticamente ofender o próprio Zeus!

Zeus: Claro que é! (Troveja).

Têmis: (Realizada pelo ódio que acendeu em Zeus). Uma ofensa imperdoável!

Zeus: (Troveja mais uma vez). Imperdoável! O que foi que eles fizeram para ofender a Mimia e a Ireninha? Elas estão bem? Já se recuperaram da afronta? Onde estão minhas deusinhas? Onde estão minhas queridas?

Têmis: (Valoriza a situação). Ah, sabe-se lá se algum dia elas vão se recuperar de tamanha ofensa...

Zeus: (Troveja). Não posso mais aguentar, me diga o que esses mortais imbecis fizeram para que eu me vingue com justeza.

Têmis: Eles...

Zeus: ... roubaram algum poder das meninas?

Têmis: Não! Eles...

Zeus: ... almejaram ter mais disciplina do que a própria Eunômia e mais paz do que Ireninha?

Têmis: Não! Eles...

Zeus: ... reuniram-se a outros deuses para destruir minhas deusinhas?

Têmis: Não! Na verdade, eles...

Zeus: (Começando a duvidar da culpa dos mortais).... eles o quê, Têmis? O que eles fizeram?

Têmis: Eles não valorizam a presença delas! É isso! Os mortais não ligam para a Disciplina nem mesmo para a Paz!

Zeus: (Acalma-se por completo). Ah, é isso? (Solta um peido). Putz, esse negócio de trovejar acaba com os meus intestinos. Já não falei para não me deixar nervoso à toa?

Têmis: À toa? Você acha que isso não é ofensa grave?

Zeus: Ah, Têmis, os mortais são apenas humanos, com estrutura fraca; não sabem o que querem e não valorizam o que é bom!

Têmis: (Tentando acender a chama do ódio de Zeus mais uma vez). Eu continuo achando que é uma ofensa grave feita às meninas, a mim e, quer saber?, a você também! Você deveria tomar uma providência quanto a isso...

Zeus: (Procura abraçar Têmis para voltar de onde pararam). Ih, Tetê, não podemos levar tudo a ferro e fogo não, senão não faço outra coisa a não ser tomar providência 
contra os mortais. Onde a gente estava mesmo? (Tenta beijá-la).

Têmis: Não, Zeus, me largue! Já falei que não quero... parece que não me ouve... e já que não me ouve, de agora em diante estou em greve!

(Do lado direito do palco).

Corifeu: Têmis, a Justiça Divina está em Greve!

Coro: Em greve? (Os participantes do coro se olham entre si procurando entender a frase. Fazem gestos de que não compreendem, mas repetem). Em greve!

(Do lado esquerdo do palco).

\section{Hermes:}

(Alcança um saco de pipoca e os óculos 3D, que estão atrás do pilar em que se encontra sentado).

Por essa eu não esperava

Quem imaginaria uma coisa dessas

Uma deusa em greve fabricava

Estratégias assim tão travessas.

Se bem conheço meu paizão,

Para se satisfazer encontrará outras formas

E não aceitará tal condição

Imagine só, Têmis estipular a Zeus as normas...

(Do centro do palco).

Zeus: Em greve?

Têmis: (Vendo que conseguiu a atenção de Zeus). Isso mesmo: em greve! Agora que eu não transo, não transo e não transo mesmo!

Zeus: Mas como assim em greve?

Têmis: Greve sexual, meu querido. Nunca ouviu falar? Táticas empregadas há muito pelas mortais. Lembro-me até que Lisístrata conseguiu finalizar uma guerra entre espartanos e atenienses assim.

Zeus: (Despeitado). Agora você segue estratégia de mortais? (Irônico). Está se rebaixando muito, Têmis...

Têmis: É? Você acha? Mas deu certo!

Zeus: Entre mortais, talvez, mas você acha mesmo que eu, o poderoso Zeus (Troveja. Têmis faz uma expressão de desdém para aquele som). Ih, foi acidental... força do hábito para impressionar os mortais... mas, você acha que eu, Zeus, vou me deixar levar por uma greve?

Têmis: Se não se sujeitar, pode voltar a zanzar por aí e procurar outras deusas, quem sabe mortais, que eu sei que até com essa laia você já se meteu.

Zeus: Ah, as mortais são boas para lhe fornecer técnicas de convencimento, mas inferiores demais para ser traçadas?

Têmis: (Desconversa se passando por ofendida). Que jeito de falar... traçadas. Eu, no seu lugar, usaria termos melhores, caro Zeus! Termos mais apropriados a sua condição.

Zeus: Ah, Têmis... Tetê... vamos parar de inventar pretexto para brigar. Vem cá, vem... 
Têmis: É sério, Zeus. Estou em greve: não transo, não transo, não transo!

Zeus: (Tentando levar na esportiva). Tá bem... vou entrar no seu jogo erótico de poder... Se você está em greve é porque está pleiteando algo. Se a greve é sexual e direcionada a mim, acredito que é algo que você queira de mim. Estou certo?

Têmis: Não!

Zeus: (Confuso). Não?

Têmis: Não! Está errado.

Zeus: Como posso estar errado. Se você está em greve é porque está reivindicando algo, não é?

Têmis: Claro que é!

Zeus: Ué, se você está fazendo greve comigo, é porque você quer algo de mim, não é?

Têmis: Não! É aí que você se engana! Eu quero algo dos mortais.

Zeus: Dos mortais? Então você está fazendo greve com a pessoa errada.

Têmis: Não estou não!

Zeus: Se seu problema é com os mortais, então por que você não faz greve com eles? O que eu posso fazer, Tetê? O problema é em outro departamento...

Têmis: (Irônica). Mas não é você o grande Zeus? Você pode tudo!

Zeus: Ah, Tetê, mas até mesmo o grande Zeus tem limitações... mas diga lá, o que você quer dos mortais?

Têmis: Quero que eles valorizem minhas filhas! Quero que eles evoquem a disciplina...

Zeus:... Ah, mas isso lá para o lado da Europa e da Ásia tem muito mortal que leva a sério!

Têmis: Mas eu quero que no Brasil os mortais também a evoquem!

Zeus: Mas claro que tem gente lá que evoca a Mimia!

Têmis: Não, Zeus, eu não quero um ou outro; não quero uma meia dúzia de gatos pingados, quero a humanidade!

Zeus: Está bem, vou ver o que eu posso fazer! (Volta a tentar abraçar Têmis).

Têmis: Mas não é só isso não.

Zeus: Não?

Têmis: Não! Se só disciplina bastasse, não existiriam mais problemas, né? Eu quero que essa disciplina evocada em Eunômia faça os mortais melhores!

Zeus: Ah, Nega,... aí você complica a minha vida!

Têmis: Quero que a disciplina gere autocontrole!

Zeus: Ih, ferrou de vez!

Têmis: Tem mais! Não quero só respeito com Mimia não! Quero que os mortais adorem Irene também!

Zeus: Você não acha que está reivindicando demais, Tetê?

Têmis: Meu amor, o que adianta disciplina e autocontrole se não for para promover a paz? (Procura seduzir Zeus em sua lógica). Não é por isso que Ireninha é sua favorita?

Zeus: ... é....

Têmis: Então, amor, se os mortais começarem a tratar nossas duas filhas com respeito, eu penso em gerar Diké, a justiça terrena.

Zeus: Vai pensar, não, né, Tetê, vai liberar de vez; vai acabar com a greve!

Têmis: (Dramática). Eu não vou gerar mais uma filha, carregá-la em meu ventre, 
nutrindo em minhas entranhas com tudo que é necessário para que ela tenha a força de ser quem ela será, depois amamentá-la em meus seios...

Zeus: ... ah, e que seios! (Tenta agarrá-la).

Têmis: Pare, Zeus, porque essa parte é para ser meio melodramática, para apelar aos sentimentos do espectador. Se você começa de sacanagem, quebra o espírito da coisa e ninguém leva a sério o que tenho para dizer! (Aponta para a platéia). Sai todo mundo do teatro sem fazer nem um tantinho de reflexão, só porque você quebrou com a seriedade do meu discurso!

Zeus: Está bem, foi mal! Não interrompo...

Têmis: Onde eu estava mesmo?

Zeus: Falando sobre seus lindos seios...

Têmis: Ah, me lembrei! Eu não vou gerar uma filha, amamentá-la em meus seios, educá-la na melhor escola do Olimpo para depois, na hora dela ter de encarar a vida profissional, ficar desempregada porque os humanos não querem saber de justiça! Poupe-me o esforço, Zeus! Poupe-nos do fracasso de nossa filha!

(Do lado esquerdo do palco).

\section{Hermes:}

É, Zeus, a reivindicação é plausível,

Parece ter procedência.

O que não parece crível

É que os mortais tomem tenência.

Em um tempo futuro, com outra mentalidade

Bastava o uso da camisinha

Para com Têmis transar à vontade

Sem se preocupar com a "Coisinha".

(Do centro do palco).

Zeus: Olhe como fala da Tetê, moleque!

Têmis: (Ignorando Hermes). Então, Zeus o que me diz? Me garanta que não é em vão que Diké nascerá?

Zeus: Como posso garantir?

Têmis: Sendo Zeus, você deveria poder...

Zeus: Você sabe que não é bem assim... há limites na minha ação, já falei isso para você! Você sabe que nem mesmo eu posso mudar o que as Moiras fiarem, sortearem e decretarem...

Têmis: (Carinhosa). Eu sei, Zezinho, mas não há um jeito? Uma maneira de tentar fazer com que os mortais valorizem nossas filhas. Dá-nos tanto trabalho criá-las, para entregarmos aos mortais que pouco respeito e devoção mostram a elas...

Zeus: Podemos apelar!

Têmis: Vai colocar fogo e acabar de vez com a raça humana?

Zeus: Não. Apelar mesmo, com a boca. Podemos conversar com os mortais e ver o que pode ser feito, tirar-lhes, quem sabe, alguma promessa, sei lá o quê.

Têmis: Mas isso não combina com você! O grande Zeus se sujeitando aos mortais e a eles pedindo auxílio?

Zeus: É, minha Nega, com tanto sacrifício assim acabam me comparando com aquele deus dos cristãos. Mas, corro o risco, você vale a pena. Já me transfigurei em 
chuva de prata, Touro e até em mortal para conseguir o que queria (Têmis faz meio que uma expressão de brava diante da lembrança dos affairs com outras deusas e mortais)., por que não me transformaria em humilde para a conquistar? Vou aos mortais! Você me acompanha? (Têmis acena que sim com a cabeça).

(Do lado esquerdo do palco).

\section{Hermes:}

(Até então sentado, levanta-se e acompanha andando o máximo que pode para ver o que acontecerá do outro lado do palco).

Da Platéia todos podem ver?

Porque do meu ângulo não afianço

Todas as cenas absorver.

Qualquer coisa daqui mesmo me balanço.

(Do centro do palco).

Zeus: (Com a voz muito grave). Mortais, ó, mortais... (Troveja).

Têmis: Que jeito estranho de falar. Que palhaçada é essa?

Zeus: Palhaçada nenhuma! É o jeito apropriado dos deuses falarem com os mortais. Pelo visto você conversa muito pouco com eles. Está meio desinformada, Tetê!

Têmis: Ô, Zeus, você quer transar ou enrolar? Já se esqueceu que você só está falando com os mortais para que eu acabe com a greve de sexo? Então não enrola, diz logo o que tem de dizer, curto e grosso, porque isso aqui é uma farsa, não é tragédia não!

Zeus: (Meio a contragosto). está bem, está bem... (Dirige-se aos mortais). Ô pessoal... (Assovia para chamar a atenção do Corifeu e do Coro).

(Do lado direito do palco).

(Corifeu e Coro se levantam e começam a prestar a atenção).

Corifeu: Quem a nós deseja falar?

Coro:

Ó, é uma voz vinda do céu!

Piedade! Piedade!

Não queremos ser devorados!

Que terror! Que horror!

Tememos ser massacrados!

O que pode uma voz vinda do céu

Querer falar conosco?

Corifeu:

Esperem aqui, irmãos,

Avanço até o pico mais alto desta montanha

(Dirige-se à platéia).

Platéia, finja que tem uma montanha aqui, tá bom?

(Volta a falar com o coro).

Para saber o que os deuses querem a nós comunicar.

(Do lado esquerdo do palco). 


\section{Hermes:}

Uma coisa me escapa

Porque de todos a falar

Eu sou o único chapa

Que tenho de rimar?

(Do centro do palco).

Têmis: (Sentindo-se vingada. Ri pérfida). Porque o panaca aqui é você! Agora silêncio aí do seu lado, porque Zeus tem algo importante a pronunciar!

Zeus: (Ao Corifeu. Limpa a garganta). Mortal, sou eu, o grande Zeus. (Troveja. Para Têmis). É mais forte do que eu, quando vejo já trovejei. Ah, me deixe falar do meu jeito mesmo que vai mais rápido. (Têmis dá de ombros).

(Do lado direito do palco).

\section{Corifeu:}

Zeus, temível Zeus,

Por que se dignas a conosco falar?

É um oráculo prevendo a desgraça?

Alguma peste nos assolará?

Algum sangue derramado

que as fúrias querem clamar?

Diga, ó Zeus,

O que o trazes a nossa morada terrestre?

(O Coro se aproxima).

Coro:

Zeus, grande Zeus,

Tememos o contato com os deuses!

Vivemos uma vida em nós mesmos

E aos deuses só sabemos ofertar

Comidas, festas, jogos e bebidas.

Mas comunicação de verdade pouco temos

Nem sabemos se nós, humanos,

Temos a ciência de com as divindades nos relacionar.

Entretanto, falas conosco

E veremos no que isso vai dar.

(Do centro do palco).

Têmis: Aproveite, Zezinho! Parece que os mortais estão abertos ao diálogo.

Zeus: (Olha apreensivo para Têmis). Sei não, sei não. Eles falam inicialmente assim, com essa voz mansa, mas na hora do "vamos ver", eles não levam a sério as nossas prescrições.

Têmis: Tenta, Zezinho, tenta! Não custa tentar! Alguma vez eu já o aconselhei de maneira errada? Você se lembra daquela vez em que você lutou contra meus irmãos, os Titãs? O que foi que eu lhe disse?

Zeus: Para cobrir meu escudo com a pele sagrada da cabra Amaltéia.

Têmis: $E$, depois de seguir minha sugestão, quem foi que ganhou a batalha?

Zeus: (Meio mecanizado). Fui eu. 
Têmis: $E$ quem foi que teve a idéia da Guerra de Tróia, para dar uma equilibrada demográfica na terra?

Zeus (Totalmente mecânico). Foi você.

Têmis: E a quem os seus irmãos do Olimpo sempre pedem conselhos?

Zeus: (Já um pouco irritado). ... a você...

Têmis: E quem ensinou Apolo as técnicas da mântica, a parte decimal dos números?

Zeus: (Totalmente sem paciência). foi você, foi você! Seus conselhos são ótimos, mas se não me deixar falar com os mortais, essa farsa vai demorar mais do que pode. Me deixe falar?

Têmis: (Dá de ombros). Ué, quem o está impedindo? Fale...

Zeus: (Aos mortais). Mortais, ó, Mortais. (Troveja. Têmis revira os olhos em sinal de impaciência). Tenho algo a lhes dizer.

(Do lado direito do palco).

Coro:

Nomeamos o nosso chefe para falar com tamanha divindade.

Não queremos nos aproximar diretamente,

Porque tememos o fogo celeste

Que a tudo devora!

Como somos mortais

Corre em nossas veias a covardia

E preferimos sacrificar um só

Do que o nosso grupo inteiro.

(Ao Corifeu). Vá, Corifeu, e fale com Zeus!

Corifeu:

Como representante do coro

Estou aqui, temível Zeus.

O que queres de mim?

(Do centro do palco).

Zeus: Dei-lhes uma filha, Eunômia, para que vocês tivessem disciplina e vivessem uma vida social organizada e equilibrada. Mas a humanidade não a considera importante. Quero que vocês prestem a atenção nos princípios e ensinamentos que ela pode lhes gerar.

Têmis: (Apoiando Zeus). Muito bem, Zezinho! Falou bonito! Não se esqueça de falar de Ireninha!

Zeus: (Para Têmis). Ah, é mesmo, Ireninha! (Para os mortais). E tem mais uma coisa, Mortais, ó, Mortais (Troveja).. De pouco adianta ter tanta disciplina e autocontrole se você igualmente não considerarem Irene, a Paz. Como Zeus, cheio de poder, ordeno-Ihes que vivam com disciplina e paz!

Têmis: (Orgulhosa de Zeus). Zezinho, você fala brilhantemente! Adorei!

Zeus: (Feliz porque agradou Têmis). Gostou mesmo? Agora vamos ver o que eles vão responder...

(Do lado direito do palco).

Corifeu:

Preciso levar tais palavras aos outros 
E ver o que os demais

Têm a dizer sobre isso.

(Corifeu e Coro confabulam. Parecem ter dificuldade para chegarem a um consenso).

(Do centro do palco).

Têmis: (Depois de uma breve pausa, ela demonstra inquietação. Torce as mãos). Ih, Zeus, não estou gostando nada dessa demora. Sei lá, de repente eles precisavam sentir mais temor, mais medo...

Zeus: (Também apreensivo). Tá vendo? A culpa foi sua!

Têmis: (Na defensiva). Minha??? Por que a culpa é minha?

Zeus: Porque você ficou me apressando e me mandou falar de qualquer jeito com eles... Não deveria ter chamado o coro de pessoal; não deveria ter assoviado... Tá vendo, deu tudo errado. Perderam o respeito por mim. Culpa sua!

Têmis: Deixe de ser pessimista, Zeus! Em vez de ficar aí pensando no pior, vai ver que eles estão arrumando um jeito de lhe obedecer. Você tem cada uma... me culpar... e, outra coisa, eu não falei para você chamá-los daquele jeito esculhambado não, eu falei para você não enrolar, é com-ple-ta-men-te diferente!

(Do lado esquerdo do palco)

Hermes:

Em toda a minha vida de eternidade

Nunca experimentei coisa igual

Mostra-se uma certa anormalidade

Esse longo silêncio do mortal.

(Denotando uma certa felicidade).

Será que pela primeira vez

Alguém vai negá-lo a obediência

E meu pai vai perder a altivez

E isso desencadeará sua decadência?

Ah, que essa eu não perco por nada

Ver Zeus cair assim no abismo

E a Humanidade se sentindo habilitada

De apresentar todo seu cinismo!

Quem sabe o dia vai chegar

Em que em vez de deus mensageiro

Eu consiga mesmo agregar

Muitos devotos aqui e no estrangeiro

Ser garoto de recado é uma porcaria

A gente fala, fala e não ganha um tostão

Desse jeito eu preferia trabalha na padaria,

Lá, pelo menos, eu comeria muito pão.

(Do centro do palco).

Zeus: (A Têmis). Sei, sei... agora vamos ficar em silêncio, porque acho que eles acabaram a conferência. (A Hermes). Psiu! Silêncio aí também, Hermes!

(Do lado direito do palco). 
Corifeu: (O Coro olha para o Corifeu apoiando-o).

Com o consentimento de meus iguais

Dirijo-me a ti, poderoso Zeus.

Aceitamos a admoestação...

(Alívio de Zeus e expressão de insatisfação de Hermes).

Mas com um pequeno senão...

(Do centro do palco).

Têmis: Como assim um pequeno senão?

Zeus: Espere, nega, vamos ouvir o que ele tem a dizer!

(Do lado direito do palco).

Corifeu:

Acreditamos que tuas palavras são sábias

E que têm real valor!

Mas não entendemos uma coisa:

Como os deuses podem nos propor disciplina e paz,

Quando os céus vivem em guerra

E Têmis briga com Hermes

Que por sua vez a ti inveja...

Ó, poderoso Zeus!

Queremos Ihe obedecer,

Mas precisamos de um exemplo vindo de cima!

(Do centro do palco).

Têmis: Sabia que não deveria brigar na frente dos serviçais, eles sempre usam isso contra a gente depois! Não se pode dar intimidade!

Zeus: Ih, Tetê... E agora? O que a gente responde?

Têmis: $O$ jeito é sermos justos e aceitarmos o negócio! Vamos evitar a briga aqui no mundo celestial! Mas avisem para os mortais que isso vai lhes custar um preço: que junto a Eunômia e Irene, Ihes dou Diké, a justiça terrena. Mas não vamos tolerar que eles se esqueçam de obedecer, seguir e amar às três!

Zeus: (Feliz porque vai transar, celebra!) Eh, que o mais beneficiado sou eu! (Beija Têmis). Você é maravilhosa, meu amor! Isso significa que a greve acabou?

Têmis: Depende da resposta dos mortais, portanto, trate de os convencer!

Zeus: Deixe comigo que vou caprichar! (Aos mortais). Mortais, ó, Mortais (Troveja). Seu discurso é convincente e há algum bom juízo no que vocês pleiteiam. E por tamanha sabedoria, não Ihes concedo só disciplina e paz para serem seguidas; dou-lhes também Diké, a justiça terrena, para que vocês tenham os benefícios dos preceitos da justiça. Se vocês a seguirem, terão uma vida reta e feliz!

(Do lado direito do palco).

Corifeu:

Estamos muito lisonjeados desse presente divino receber

O povo todo aqui embaixo festeja a ti, Zeus, poderoso!

Coro:

Voltamos a nos aproximar de ti,

Pois vimos que não é fogo do céu 
Que jogarias para nos queimar.

O que nos ofertas é bom e verdadeiramente divino

Muito nos agrada!

Só esperamos poder, enfim,

Viver apreciando Eunômia, Irene e Diké!

(Do centro do palco).

Zeus: (Com chamego para Têmis). Hum, agora vamos fazer Diké? (Têmis e Zeus se beijam).

(Do lado direito do palco).

Corifeu:

(Tosse para chamar a atenção de Zeus).

Com licença, poderoso Zeus...

(Do centro do palco).

Zeus: (Zeus e Têmis param de se beijar. Com ar de superioridade). Sim?

(Do lado direito do palco).

Corifeu:

Nós vamos nos esforçar para lhe obedecer!

E honrar aquilo que lhe prometemos!

(Do centro do palco).

Zeus: (Meio impaciente). Muito me agrada a isso ouvir, se é só, tenho assuntos... divinos para serem tratados agora! (Volta a beijar Têmis).

(Do lado direito do palco).

Coro:

O que o Corifeu quer lhe dizer

É que nossa parte cabe a nós cumprir,

Mas fizemos um trato bilateral

Onde a parte que cabe aos céus

Compete aos deuses fazer.

Falaste em paz aqui na terra

E achamos que isso é muito bom!

Mas seria proveitoso termos exemplos

Das alegrias gerada pela paz

Aí também no Olimpo!

Queremos ver reconciliados

Têmis e Hermes

$E$ também não assistir

Aos ciúmes de Hermes direcionados a ti!

(Do centro do palco).

Têmis: (Olha Zeus apreensiva). Ih, vou ter de aturar aquele chato?

(Hermes faz cara de tédio).

Zeus: Mas, meu amor, essa foi a condição dos humanos...

Têmis: Está certo... Então avisa que aceitamos a reconciliação. Chame Hermes aqui 
para resolvermos logo isso!

Zeus: (A Hermes). Filho, vem cá, filhão...

(Do lado esquerdo do palco).

Hermes:

(À parte).

Zeus me chamou de filhão?

Isso não é comum nem normal!

Em minha mente há confusão,

Pois ele não costuma ser casual.

Vou responder e ver o que ele quer

Nunca o vi com tanta delicadeza

Talvez eu fature uma coisa qualquer

Melhor é responder-lhe com presteza.

(A Zeus)

Pois não, pai e dirigente,

Encontro-me aqui à sua disposição!

O que tem a me dizer é abrangente?

Causa bem ou destruição?

(Do centro do palco).

Zeus: (A Hermes). Quero Ihe convidar a vir aqui, em minha casa, festejar!

(Do lado esquerdo do palco).

Hermes:

(À parte).

Será uma armadilha cruel?

Terei de fazer uma tarefa insuportável?

Terei atrasado o aluguel?

Ou será alguma coisa amigável?

Não adianta aqui conjeturar

O negócio é ir em frente

Se a mim ele tentar matar

Vou gritar a toda gente!

(Caminha um pouco, como quem vai ao centro do palco, mas pára e retorna).

(Ao público).

Vou me aproximar de meu pai de modo informal,

Pois até agora nunca vi Zeus me tratar desse jeito.

Tanto carinho e atenção para comigo não é natural,

Até hoje, ele a mim só impôs tarefa e viu defeito.

(A Zeus).

Aqui estou meu paizão!

O que precisa com urgência me dizer?

Se for dívida, só tenho cartão,

Porque estou com grana curta para viver!

(Tira um cartão de crédito da roupa).

Zeus: Guarde isso, meu filho! Você não me deve nada! Venha até aqui para uma grande confraternização: Têmis e eu queremos lhe acolher... 
Têmis: (A Zeus, quase sussurrando). Ai, ainda por cima temos de paparicar esse moleque.

Zeus: (A Têmis). O menino está desconfiado; é preciso um certo trato para conseguir o que queremos.

Têmis: Está certo... está certo...

Zeus: Filhão, por que você ainda está aí? Venha para cá. Papai quer lhe dizer umas coisas... coisas boas!

(Hermes, ainda um pouco ressabiado, se desloca do seu lado e vai ao centro do palco. O coro e Corifeu assistem a tudo).

Zeus: Ah, filhão! Assim está ótimo! A família reunida em plena harmonia... muito bom mesmo! (Zeus abraça Hermes, que ainda se encontra desconfiado, mas responde positivamente aos carinhos paternos. Zeus aproxima artificialmente Têmis de Hermes, ambos estão desconfortáveis. Zeus mantém a todo tempo um sorriso amarelo de comerciante e observa se os mortais estão acreditando em sua farsa). Ah, que espetáculo! Bem, Mortais, ó, Mortais, nós, os deuses, cumprimos nossa parte, restam a vocês observarem as nossas leis e estatutos, por isso entrego-lhes como orientadoras Eunômia, a Disciplina, Irene, a Paz, e Diké, a Justiça Terrena, que em breve Ihes darei, se me derem licença...

(O Corifeu e Hermes saem do palco com uma parte do coro. Um pano branco - com uma luz iluminando de modo a produzir o efeito de sombra - é introduzido no palco pela outra parte do coro e colocado de fora-a-fora no palco. As sombras devem ser projetadas como um prenúncio de dança. Tudo deve ser ritmado por uma música instrumental, como se sob o efeito da dança. Assim, nesse clima, Zeus beija Têmis e, juntos, produzem Diké. O jogo de sombras seguinte mostra o nascimento de Diké. A seguir, Eunômia e Irene se reúnem a Diké e as três bailam, inicialmente atrás do pano e, depois, dançam diretamente para a audiência. O bailado tematiza a harmonia entre a paz, a disciplina e a justiça. Juntam-se às Horas as três Moiras, que seguram a todo tempo em suas mãos fios, que representam o destino, como se a todo o tempo elas fiassem. O pano é retirado, enquanto Zeus e Têmis, de um dos lados do palco, convidam Hermes a assistir a dança das Horas e das Moiras. Hermes retorna ao palco e posiciona-se ao lado dos outros dois deuses e, juntos, assistem ao balé com uma expressão de satisfação. A dança das Moiras, que ocorre concomitantemente com a das Horas, deve se assemelhar a um contínuo tear, uma confecção de teia, que ora emaranha ora desenlaça o destino dos mortais. Desse modo, Coro e Corifeu são atraídos para a dança: alguns possuem aspectos de satisfação e felicidade; outros demonstram tristeza e insatisfação. Alguns se encontram atentos e desconfiados, outros avoados ou mesmo abestalhados. Depois os aspectos faciais e gestuais dos mortais são trocados e aqueles que estavam satisfeitos tornam-se insatisfeitos e os que estavam tristes agora se apresentam alegres. É importante que se perceba que o destino é traçado sob um emaranhado de condições e sentimentos humanos, por isso o vai-e-vem das distintas emoções que percorrem todos os componentes do Coro, incluindo o Corifeu. Por fim, a música instrumental se transforma em um grande samba e Zeus, Têmis e Hermes entram na dança).

(Cai o pano). 